\title{
Statistical Analysis of Basic Necessities and Facilities Related to Human Development Index
}

\author{
Anam Javaid ${ }^{1}$ \\ Shahbaz Nawaz ${ }^{2 \rtimes}$ (D) \\ Muhammad Waheed ${ }^{3}$ (iD
}

'Lecturer, Department of Statistics, The Women University, Multan, Pakistan; (PhD Scholar) School of Mathematical Sciences, Universiti Sains Malaysia, Penang, Malaysia.

Email:anamjavaido786@yahoo.com

VVisiting Lecturer, Bahauddin Zakariva University Multan, Pakistan; (PhD Scholar) School of Quantitative sciences, college of Arts and Sciences, Universiti Utara Malaysia.

Email:anamjavaido786@yahoo.com

${ }^{3} M B A / M S$ in Finances, Institute of Management Sciences; Visiting faculty Member, Bahauddin Zakariya

University Multan, Pakistan.

Email: muhammadwaheedfaiz@gmail.com

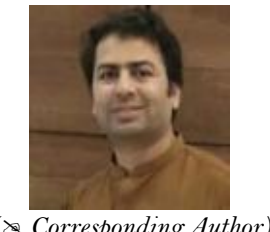

\begin{abstract}
Human Development index measures the status of economy for a country. It is based on education Index, health index and on gross domestic product (GDP). Human Development index can also be seen by looking the basic necessities and facilities that are available to people in a specific area. In this research, the analysis is made on the basis of basic necessities and facilities for Multan district that people have in the specific areas. The data has been taken from MICS Survey (2007-2008) with 2892 observations. Cluster sampling is used in collecting observations. The data is collected through different developed and underdeveloped areas of the district. The purpose is to observe the availability of necessities and facilities to that area. Frequency distribution is used for assessing the facilities that people have in their homes. The results indicate that there is a great difference between availability of basic necessities and facilities between the people belonging to developed and underdeveloped areas. So by focusing these factors, the difference between the developed and underdeveloped areas can be reduced.
\end{abstract}

Keywords: Human development, Frequency, Economy, Facilities, Necessities, Survey.

Citation | Anam Javaid; Shahbaz Nawaz; Muhammad Waheed (2019). Statistical Analysis of Basic Necessities and Facilities Related to Human Development Index. Asian Journal of Social Sciences and Management Studies, 6(2): 39-44. History:

Received: 2 September 2019

Revised: 4 October 2019

Accepted: 6 November 2019

Published: 16 December 2019

Licensed: This work is licensed under a Creative Commons

Attribution 3.0 License $(\mathrm{cc})$ )

Publisher: Asian Online Journal Publishing Group
Acknowledgement: All authors contributed to the conception and design of the study.

Funding: This study received no specific financial support

Competing Interests: The authors declare that they have no conflict of interests.

Transparency: The authors confirm that the manuscript is an honest, accurate, and transparent account of the study was reported; that no vital features of the study have been omitted; and that any discrepancies from the study as planned have been explained.

Ethical: This study follows all ethical practices during writing.

\section{Contents}

1. Introduction

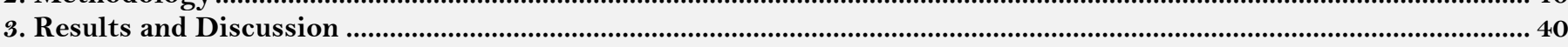

4. Conclusion 49

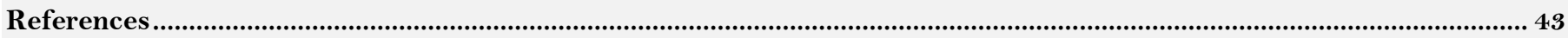




\section{Contribution of this paper to the literature}

The study contributes to the existing literature by examining the basic necessities and facilities for Multan district of Pakistan that people have in the specific areas.

\section{Introduction}

Human development index enable us to judge the development level of a country or for a specific area.it is basically depends on it depends on education Index, health index and on GDP. If HDI of a country is increased, it's mean that its stability level has been increased and the people of that country or of that area has many facilities as compare to the underdeveloped country or areas. In this research, the study is made on analysing the basic necessities and facilities that people have in different areas of Multan District. The data is based on MICS (Multiple Indicator Cluster Survey) data of 2007-2008 for Multan district. Any works has been done on HDI. Quimbo et al. (2008) in their study found relationship between health, poverty and education by using data Quality Improvement Demonstration Study (QIDS) on children those were under 5 years from Philippines. Huisman and Smits (2009) studied primary school enrolment by taking data from 30 different developing countries for 340 districts with 220,000 children observations (Idrees and Ahmad, 2010) studied the inequalities in food and non food consumption by taking data in Pakistan and used Gini coefficient as measure of inequality. Zhao and Glewwe (2010) studied education school attainment of children for poor and rural areas of China. Faridi et al. (2010) studied education impact on employment in Pakistan by using the data of rural area from Bahawalpur district. Abbas and Hiemenz (2011) studied different social, political, economical and demographic variables of health care in Pakistan by taking data from 1972-2006. Peykarjou et al. (2011) examined relationship between health and economic growth in Islamic Conference Organization members by using data from 2001-2009. Ahmad and Riaz (2011) studied the poverty in Pakistan by using data from 1974 -2009. Ajmair and Akhtar (2012) analysed factors effecting on household consumption. They used data from district Bhimber, AJK (Azad Jammu Kashmir).Many reserachers are working on Human Development index as Miletzki and Broten (2017) worked on a study to show that human development is considered as a freedom for the residents. Mukhtar and Javaid (2018) conducted a study among students for different factors like income, job, status of their parents effecting on the pocket money. Later on Kail and Cavanaugh (2018) performed a study to review the life span in HDI for people with different standard of living. Javaid and Nawaz (2018) reviewed about the study realted to agriculture side as it is a main source of HDI. Vondracek et al. (2019) worked out for a career development approach of people after that Javaid et al. (2018) conducted a study on review of different reserachers related to HDI. One of the study conducted by Ghaffar et al. (2019) for the economic growth.

From the above literature, it is clear that many people are still working on HDI as it is important for a country. So the current study is about the basic facilities and necessities of HDI that has its importance in calculation of human development index.

\section{Methodology}

Frequency distribution is used to study the availability of basic necessities and facilities that people have in different areas of Multan District. The study indicated the distribution of different basic necessities and facilities that people have and also it indicate the frequency of people that do not have that facilities.

Different questions were asked from the people about the facilities and basic necessities that they have in their homes. It help us to distinguish the people belonging to developed, developing and under developed areas.

\section{Results and Discussion}

Different factors are taken related to HDI from MICS (multiple indicator cluster survey) of 2007-2008 for Multan region in different towns like Mumtazabad, Bosan Town, Mumtazabad, Sher shah Town,Shah-Rukn-eAlam, Shujabad Town Jalal Pur Peer Wala. Total of 2892 observations are used for the analysis purpose. Different questions were asked from people regarding different facilities related to HDI and the frequency distribution for them can be seen as below. Cluster Sampling is used in taking observations.

Electricity is considered as the basic main facility as without electricity, it is difficult to survive as the other facilities also depend on electricity so one of the important questions was for the availability of electricity in 2007 to 2008 survey and the answers were observed in Table 1.

\begin{tabular}{c|c}
\multicolumn{2}{|c}{ Table-1. Frequency distribution for electricity. } \\
\hline Electricity & Count \\
\hline Yes & 2708 \\
\hline No & 184 \\
\hline Total & 2892 \\
\hline
\end{tabular}

It can seen that from 2892 people, 2708 have the electricity facility while 184 did not have electricity facility. It means that in the survey, majority of the people had this facility while few people did not have the facility and he reason can be that they belong to the less developed area. Another important main facility is Gas as it is considered as a basic need for the people even for cooking, this facility matters a lot. So the answers can be analysed as in Table 2.

Table-2. Frequency distribution for sui gas.

\begin{tabular}{c|c}
\hline Sui Gas & Count \\
\hline Yes & 1431 \\
\hline No & 1461 \\
\hline Total & 28992 \\
\hline
\end{tabular}


It can be seen that almost there is a half ratio that people do not have this facility and again the reason can be that the people belong to backward areas. For interaction to the world, social media is also considered as the important factor in facilities so regarding that, different questions were asked and the answers can be seen as in Table 3.

\begin{tabular}{c|c} 
Table-3. Frequency distribution for radio. \\
\hline Radio & Count \\
\hline Yes & 1394 \\
\hline No & 1498 \\
\hline Total & 2892 \\
\hline
\end{tabular}

The question was asked whether they have radio or tape recorder and from the answer, it is clear that not so many people have the facility of radio or tape recorder in that survey time. Another question was related to facility of T.V and the answers can be seen as in Table 4.

\begin{tabular}{c|c}
\multicolumn{2}{|c}{ Table-4. Frequency distribution for T.V. } \\
\hline T.V & Count \\
\hline Yes & 1827 \\
\hline No & 1065 \\
\hline Total & 2892 \\
\hline
\end{tabular}

It is clear that 1827 have T.V in their homes out of 2892 people. Another facility was Cable TV and the answers can be seen as in Table 5 .

\begin{tabular}{|c|c}
\hline Table-5. Frequency distribution for cable T.V. \\
\hline Cable TV & Count \\
\hline Yes & 844 \\
\hline No & 2048 \\
\hline Total & 2892 \\
\hline
\end{tabular}

So out of 2892, only 844 have cable facility while other people do not have this facility. Another question was regarding telephone facility in their home as it is also considered as the important facility for connection of the people and the responses were as in Table 6.

\begin{tabular}{c|c}
\multicolumn{2}{|c}{ Table-6. Frequency distribution for telephone. } \\
\hline Telephone & Count \\
\hline Yes & 461 \\
\hline No & 2431 \\
\hline Total & 2892 \\
\hline
\end{tabular}

The answers reveal that majority of the people do not have the telephone facility in their home. Instead of the telephone, mobile phone facility is now everywhere so one question was asked about the mobile phone facility and the answers can be analysed as in Table 7 .

\begin{tabular}{c|c}
\multicolumn{2}{c}{ Table-7. Frequency distribution for mobile phone. } \\
\hline Mobile phone & Count \\
\hline Yes & 1891 \\
\hline No & 1001 \\
\hline Total & 2892 \\
\hline
\end{tabular}

It is clear that 1891 have the mobile facility while other people did not have this facility at their home at that time. Another important facility is the computer system as it is a great source of social connection even from this facility, people also can have many chances for online jobs so the answers can be analysed as in Table 8 .

\begin{tabular}{c|c} 
Table-8. Frequency distribution for computer. \\
\hline Computer & Count \\
\hline Yes & 257 \\
\hline No & 2635 \\
\hline Total & 2892 \\
\hline
\end{tabular}

The above answers reveals regarding the computer system in their houses and it can be seen that in 2007 to 2008 , many people did not have this facility in their homes but now a days, the computer facility is common in almost every house as without this, many works cannot be done. Internet connection is also very important factor now a days as if any household has a computer facility then it is considered as incomplete without internet connection so the answers for this facility are as in Table 9 .

\begin{tabular}{c|c} 
Table-9. Frequency distribution for internet connection. \\
\hline Internet connection & Count \\
\hline Yes & 144 \\
\hline No & 2748 \\
\hline Total & 2892 \\
\hline
\end{tabular}


The answers show regarding facility of internet connection and it is clear that majority people did not have internet facility in their homes at that time. Refrigerator is a basic facility for the people so one question was regarding the facility of refrigerator and the answers were as in Table 10.

\begin{tabular}{c|c}
\multicolumn{2}{c}{ Table-10. Frequency distribution for refrigerator. } \\
\hline Refrigerator & Count \\
\hline Yes & 1147 \\
\hline No & 1745 \\
\hline Total & 2892 \\
\hline
\end{tabular}

It can be seen that majority people did not have refrigerator facility in their homes. One important facility is air conditioner as it is becoming a necessity now days so in the survey, this is also considered as the important question and the answers can be seen as in Table 11 .

\begin{tabular}{c|c} 
Table-11. Frequency distribution for air conditioner. \\
\hline Air conditioner & Count \\
\hline Yes & 231 \\
\hline No & 2661 \\
\hline Total & 2892 \\
\hline
\end{tabular}

It is clear that only 231 people had air conditioner facility in 2008 survey. This can be the reason that at that time, these facilities were not so common among people. Another this kind of facility is washing machine and the answers can be seen as in Table 12 .

\begin{tabular}{c|c} 
Table-12. Frequency distribution for washing machine. \\
\hline Washing machine & Count \\
\hline Yes & 1427 \\
\hline No & 1465 \\
\hline Total & 2892 \\
\hline
\end{tabular}

The answer for the question can be seen as above and it is clear that majority of the people did not have the facility of washing machine in that survey. The results are in Table 13.

\begin{tabular}{c|c}
\multicolumn{2}{|c}{ Table-13. Frequency distribution for microwave. } \\
\hline Microwave/cooking range & Count \\
\hline Yes & 174 \\
\hline No & 2718 \\
\hline Total & 2892 \\
\hline
\end{tabular}

From the above answers, it is clear that many people did not have the facility of microwave or the cooking range while only 174 have the cooking range facility at that time. The responses for stitching machine facilities can be observed as in Table 14 .

\begin{tabular}{c|c} 
Table-14. Frequency distribution for stitching machine. \\
\hline Stitching machine & Count \\
\hline Yes & 2114 \\
\hline No & 778 \\
\hline Total & 2892 \\
\hline
\end{tabular}

From the above result, the majority people have the stitching machine facility while only 778 people did not have the stitching machines in their homes. Another question regarding iron facility was asked and the responses can be seen as in Table 15 .

\begin{tabular}{c|c}
\multicolumn{2}{c}{ Table-15. Frequency distribution for iron. } \\
\hline Iron & Count \\
\hline Yes & 2278 \\
\hline No & 614 \\
\hline Total & 2892 \\
\hline
\end{tabular}

Majority of the people had iron facility in their homes while only 614 did not have the facility of iron in their homes. Water filter is considered also one of the important facility. The question was also asked for it and the answers were as in Table 16.

\begin{tabular}{c|c} 
Table-16. Frequency distribution for water filter. \\
\hline Water filter & Count \\
\hline Yes & 137 \\
\hline No & 2755 \\
\hline Total & 2892 \\
\hline
\end{tabular}

The above results shows that not so many people had the water filter facility as only 137 people had the water filter facility in their houses. 


\begin{tabular}{c|c} 
Table-17. Frequency distribution for motorcycle. \\
\hline Motorcycle/scooter & Count \\
\hline Yes & 896 \\
\hline No & 1996 \\
\hline Total & 2892 \\
\hline
\end{tabular}

Majority of the people did not have the facility of scooter or motor cycle as only 896 respondents from Table 17 had the facility of motorcycle. Another transportation question was asked about the car or truck facility and the answers can be seen as in Table 18 .

\begin{tabular}{c|c} 
Table-18. Frequency distribution for car or truck. \\
\hline Car or truck & Count \\
\hline Yes & 204 \\
\hline No & 2688 \\
\hline Total & 2892 \\
\hline
\end{tabular}

The majority of people did not have the facility of car or truck at their homes as only 204 people have this facility in their homes. Another question regarding agricultural land was asked from the people and the answers can be seen as under.

\begin{tabular}{c|c} 
Table-19. Frequency distribution for own agricultural land. \\
\hline Own agricultural land & Count \\
\hline Yes & 618 \\
\hline No & 2274 \\
\hline Total & 2892 \\
\hline
\end{tabular}

The answers in Table 19 reveal that only 618 households had the facility of their own agricultural land while majority households did not have their own agricultural land. The reason can be behind that they may be did not belong to agricultural background or many of them may be working under some other person so they did not have their own agricultural land.

\begin{tabular}{c|c}
\multicolumn{2}{|c}{ Table-20. Frequency distribution for own livestock } \\
\hline Own livestock & Count \\
\hline Yes & 887 \\
\hline No & 2005 \\
\hline Total & 2892 \\
\hline
\end{tabular}

It is clear from Table 20 that not so many people have their own livestock. The reason can be again that majority of them did not belong from agricultural background.

Our main concern is regarding human development. To do this, we have found different factors, i.e. education, health, house ownership, living standard and socio economic status of people in that area. So, in our study and in previous studies, we have observed that main factor of human development are electricity, gas, TV, telephone, refrigerator, car or truck, own live stock, toilet, foreign remittances, domestic remittances, house area in marla, education at different level, main material of roof, own agriculture land, house value in RS., main material of wall, gender, type of dwelling, motorcycle or scooter, animal driven cart, mobile phone, house ownership, distance to nearest health facility, consider government utility store as beneficial to a common man, air conditioner, gender, family structure, biological child, number of sisters in a family, number of brother in a family, occupation father, education father, education mother, house wealth, rural area, average distance of school, pupil child ratio, pupil teacher s ratio, \%age of men with a white collar job, \%age of women with a white collar job, district development index, national GDP per capita, household size, Per capita expenditure, age cohort, income, and respiratory problem, index of quality of structure, number of floors, utility variables, wall and rooms are the main determinants of human development. From the above determinants, some variables we found in our study and some were found to be in previous studies conducted by different researchers for HDI.

\section{Conclusion}

The result of the study indicate about the basic necessities and facilities that people have in the specific areas. It is clear that the people belonging from developed areas have more facilities as compare to under developed areas of Multan district. It can also be seen that the people that are belonging to agricultural areas have more facilities related to agriculture as compare to others. For the further study, the latest survey can be taken for the frequency distribution study to see the comparison. Multivariate analysis can be used for identification of multiple factors.

\section{References}

Abbas, F. and U. Hiemenz, 2011. Determinants of public health expenditures in Pakistan. ZEF-Discussion Papers on Development Policy No. 158.

Ahmad, K. and A. Riaz, 2011. An econometric model of poverty in Pakistan: ARDL approach to co-integration. Asian Journal of Business and Management Sciences, 1(3): 75-84.

Ajmair, M. and N. Akhtar, 2012. Household consumption in Pakistan (A Case Study of District Bhimber, AJK). European Journal of Scientific Research, 75(3): 448-457.

Faridi, M.Z., S. Malik and R.I. Ahmad, 2010. Impact of education and health on employment in Pakistan: A case study. European Journal of Economics, Finance and Administrative Sciences, 18: 58-68.

Ghaffar, S., H. Munir, S. Nawaz and A. Javaid, 2019. The impact of international trade on economic growth: A case study of Pakistan. Asian Journal of Social Sciences and Management Studies, 6(2): 15-22.Available at: https://doi.org/10.20448/journal.500.2019.62.15.22. 
Huisman, J. and J. Smits, 2009. Effects of household-and district-level factors on primary school enrollment in 30 developing countries. World Development, 37(1): 179-193.Available at: https://doi.org/10.1016/j.worlddev.2008.01.007.

Idrees, M. and E. Ahmad, 2010. Measurement and decomposition of consumption inequality in Pakistan.The Lahore Journal of Economics, 15(2): 97-1 12.Available at: https://doi.org/10.35536/lje.2010.v15.is.a5.

Javaid, A., A. Akbar and S. Nawaz, 2018. A review on human development index. Pakistan Journal of Humanities and Social Sciences, 6(3): $357-369$.

Javaid, A. and S. Nawaz, 2018. Review analysis on agricultural sector in Pakistan. International Journal of Research and Innovation in Social Sciences, 2(10): 93-94.

Kail, R.V. and J.C. Cavanaugh, 2018. Human development: A life-span view. Cengage Learning.

Miletzki, J. and N. Broten, 2017. Development as freedom. Macat Library.

Mukhtar, I. and A. Javaid, 2018. Factor identification and usage of pocket money among students: A case study. International Journal of Research and Innovation in Social Sciences, 2(9): 36-39.

Peykarjou, K., R.B. Gollu, H. Gashti and R.B. Shahrivar, 2011. Studying the relationship between health and economic growth in OIC member states. Interdisciplinary Journal of Contemporary Research in Business, 3(8): 1041-1054.

Quimbo, S.A., A.D. Kraft and J.J. Capuno, 2008. . Health, education and the household: Explaining poverty webs (No. 2008, 09). UPSE Discussion Paper.

Vondracek, F.W., R.M. Lerner and J.E. Schulenberg, 2019. Career development: A life-span developmental approach. Routledge: 6783.Available at: https://doi.org/10.4324/9781315792705-4.

Zhao, M. and P. Glewwe, 2010. What determines basic school attainment in developing countries? Evidence from rural China. Economics of Education Review, 29(3): 45 1-460.Available at: https://doi.org/10.1016/j.econedurev.2009.10.008. 